\title{
SELF-EFFICACY AND HEALTH BEHAVIOUR: SOME IMPLICATIONS FOR MEDICAL ANTHROPOLOGY
}

\author{
Ljubiša Zlatanović \\ University of Niš, Faculty of Philosophy, Department of Psychology
}

\begin{abstract}
Summary. The study of personality characteristics and behaviours related to human health has become a key area of research within contemporary health psychology. Personality variable that has attracted a growing interest of health psychologists is the concept of self-efficacy developed by Albert Bandura within his highly influential social-cognitive or social learning theory of human behaviour. Defined generally as the individual's belief that one will be able to carry out one's plans and intentions successfully or to perform certain behaviours necessary to attain desired goals or anticipated outcomes, selfefficacy is one of the key factors in the exercise of personal control, including a control over the state of one's own health. Starting from this theoretical framework, the main purpose of this article is to provide at first a concise overview of the theory of selfefficacy, and then to consider its relationship with the various forms or patterns of behaviours related to health, as well as to suggest some possible implications of this theory for medical anthropology - especially for its applied areas that are focused on the health education, health promotion, and health protection.
\end{abstract}

Key words: self-efficacy, health behaviour, health psychology, medical anthropology.

Ills of the body may be cured by physical remedies or by the power of the spirit acting through the soul.

Paracelsus

\section{Introduction}

The idea that personality or mental states could cause both mental and physical disease and health has a relatively long history. Personality factors related to the performance of health behaviours have been either positively (e.g., optimism) or negatively (e.g., negative affectivity) associated with the practice of health behaviours (e.g., Conner and Norman, 2005). In addition, social cognitive factors (beliefs, attitudes, knowledge) are also recognized and extensively researched as important variables that determine whether or not an individual practices health behaviours. In general, personality traits or combinations of traits are seen as fundamental determinants that shape beliefs about the behaviour in question which, in turn, determine intention and behaviour. Thus, it is recognized that the impact of personality traits should be mediated by social cognitive variables (Norman and Conner, 2005). Currently, a great deal of research in psychology is focused on the relationship between various personality and cognitive factors and health-status is trying to examine how and why personality is linked to disease and health. This research interest is a part of a broader endeavour of theorists and researchers in this area to answer the following basic question: What are the major determinants of health behaviour and good health in general? 
The study of personality variables and behaviours related to human mental and physical health has become a key area of research within contemporary health psychology - an interdisciplinary field of theory and research concerned with the application of psychological knowledge and techniques to human health, disease, and healthcare (e.g., Kaptein and Weinman, 2004; Rodham, 2010). Although the primary focus has been clinical settings, interest is now also being directed towards interventions for disease prevention - especially with reference to sexual health, nutrition, smoking, alcohol and drug addiction, physical inactivity, and stress and coping. In addition, nowadays there are four main approaches to this new field of psychological inquiry: clinical health psychology, public health psychology, community health psychology, as well as critical health psychology. The topics covered have all been researched and theorized from the perspective of how health is influenced by the way people think, feel and behave. These health experiences and behaviours are seen by health psychologists as the major psychological determinants of the long-term health and quality of life (Marks, Murray, Evans, and Estacio, 2011).

In recent times, in this new discipline of applied psychology there is a great number of researches on various specific topics and issues related to human health that are based mostly on the social-cognitive approach, which emphasizes the way in which our thoughts and emotions are affected by the immediate social context (e.g., Albery and Munafo, 2008). Theoretical perspectives and models developed within this approach have been widely used in the endeavour of researchers and practitioners to account for some of the crucial issues in the field of health psychology related to the factors underlying health-impairing behaviours (e.g., smoking, unprotected sex) and health-protective behaviours (e.g., exercising, eating healthily).

It could be said that one of the key concepts in social-cognitive approach is the Albert Bandura's construct of self-efficacy. Its importance is reflected, among other things, in the fact that all the other major theoretical models of human health behaviour -such as the protection motivation theory, the health beliefs model, and the theory of planned behaviour include a measure of self-efficacy as an important component, recognizing its vital role in developing and maintaining health behaviours. In addition, it is also worth noting that selfefficacy is one of the central constructs not only in health psychology, but also in social, personality, clinical, sport and exercise psychology. It is also of key importance in recent socalled positive psychology movement - a new and rapidly expanding research field in psychology that involves a great number of researches focused on the scientific study of optimal, adaptive and healthy human functioning, as well as the study of positive aspects of human life and positive features that make human life worth living (e.g., Compton, 2005; see also Zlatanović, 2012). Literature in these disciplines of contemporary psychology covers a wide range of research topics that include the concept of self-efficacy, ranging from the selfefficacious beliefs and behaviours in various domains or circumstances to the developmental, adaptive and health benefits derived from effective self-regulation.

There are many important topics and issues related to human health that are also of special research interest in contemporary medical anthropology - the interdisciplinary field of research in various health and healing problems, encompassing a diversified range of approaches and orientations in its search of holistic understanding of the health - disease process in human cultures and societies (e.g., McElroy and Townsend, 1989). Because it is one of the aims of this article to consider some possible implications of self-efficacy theory for medical anthropology and to suggest ideas for further interdisciplinary research, for this reason it is needed to consider at first this concept and the basic premises of this theory, as well as the relevant empirical studies on the relationship between self-efficacy and various health-related domains and behaviours. 


\section{Self-efficacy: theory and conceptualization}

Personality variable that has been of growing interest to health psychologists is the concept of self-efficacy. It could be said that this concept refers to one of the most powerful but also the simplest truths: the truth that believing that we can accomplish what we want to accomplish is "one of the most important ingredients - perhaps the most important ingredient in the recipe for success "(Maddux, 2002: 277).

The concept of self-efficacy has been defined generally as the belief in one's ability to carry out one's plans or to perform a task successfully, as well as to perform certain actions necessary to attain desired or anticipated outcomes. Thus, perceived self-efficacy is concerned with people's core beliefs in their capabilities to produce a given level of attainments by their own actions. Therefore, these beliefs are judgments about what a person thinks he or she can do, not what he or she has. They are a product of a complex process of self-appraisal and selfpersuasion that relies on cognitive processing of several sources of efficacy information such as past performance accomplishments, vicarious experiences, verbal persuasion, and physiological and emotional states (e.g., Bandura, 1997). It is worth noting that self-efficacy is not a global entity or general phenomenon but rather varies across activity domains, task demands, and situational characteristics (Bandura, 1997). In other words, it refers more to the person's sense of efficacy for specific intentions or specific behaviours in the context of particular tasks, and challenging or problematic situations. Thus, it does not refer to a global personality characteristics or a personality trait that operates independently of contextual factors. This implies that expectations about efficacy depend on the particular task and context which confronts an individual. Therefore, it is not appropriate to characterize an individual as having "high" or "low" self-efficacy in general. Instead, such characterization is adequate only with reference to the specific behaviour and situation with which the perceptions of personal efficacy are linked (Bandura, 1997; Strecher et al., 1986).

This social-psychological concept was developed by Albert Bandura within his highly influential social-cognitive or social learning theory of human behavioural functioning, which has widened behaviorism's purview to include the role of observation and cognitive processes in learning and performance. One of the central questions in this theory of cognitive regulation of motivation and behaviour is the issue of causality: Do beliefs of personal efficacy contribute to human functioning? Bandura (1986) argued that this kind of belief has an important role in human behaviour, as well as that a sense of personal efficacy is the foundation of human agency and the capacity for self-regulation. Moreover, among the mechanisms of human agency, selfbeliefs of efficacy have the central role. Whatever other factors serve as guides and motivators, their roots are in the self-efficacy beliefs that influence the ways in which people feel, think, motivate themselves, and how they behave. According to Bandura $(1997,2008)$, perceived selfefficacy influences all aspects of human behaviour - the acquisition of new behaviours, inhibition of existing behaviours, and disinhibition of new behaviours. Additionally, it influences the amount of effort people will expend on a task, how long they will persist in the face of obstacles, as well as people's thought patterns and emotional reactions (Bandura, 1977, 1992, 2006). Self-efficacy beliefs produce their effects through four major processes that usually operate in concert, regulating human functioning: cognitive, motivational, affective, and decisional (choice) processes. These effects on psychosocial functioning are pervasive and diverse. In sum, self-efficacy beliefs affect: (1) whether coping behaviour will be initiated, how much self-regulative effort will be expended and how long this effort will be sustained in the face of obstacles and aversive experiences; (2) whether individuals think pessimistically or optimistically, in self-enhancing or self-debilitating ways; (3) how well they motivate themselves and persevere in the face of difficulties; (4) the quality of their emotional well-being 
and their vulnerability to emotional distress and depression; (5) resiliency to adversity; and (6) the life choices they make at important decisional points which set the course of life paths. Through these diverse means, people's beliefs in their efficacy to manage their own functioning and to exercise some measure of control over stressful events that affect their lives promote resilience to them (Bandura, 1997; 2001; Bandura and Locke, 2003).

In addition, beliefs of personal efficacy also serve as shapers of one's aspirations and performance attainments, contributing significantly to the level of motivation and performance accomplishments. They affect self-motivation through their impact on people's goals or standards of performance and aspiration. Thus, it is partly on the basis of efficacy beliefs that people choose which challenges to undertake, how much effort to invest in the pursuits, how long to persevere in the face of difficulties, and whether failures are motivating or demoralizing. According to Bandura (1997), such efficacy beliefs also shape people's outcome expectations. Thus, people of high efficacy expect their efforts to produce favorable outcomes, while those of low efficacy beliefs do not expect their efforts to produce much. The way in which people view their life circumstances is also influenced by efficacy beliefs. Those of high efficacy focus on the opportunities their life conditions present. Furthermore, even in environments with limited opportunities, they believe that constraints and obstacles can be overcome. On the other hand, individuals with low sense of efficacy are prone to convince themselves of the futility of their efforts. Because of their self-doubts, they also achieve limited success even in environments that provide many opportunities (Bandura, 1997).

It is also worth noting that there is an intriguing suggestion that self-efficacy could be viewed as one of the sources of human meaning of life. Thus, motivational perspective developed by Roy Baumeister encompasses broader psychological needs which contribute to a sense of meaning when these needs are related to hope and purpose in future-oriented goal striving. According to this perspective, major human needs related to subjective fulfillment (needs for meaning) include purpose, value, self-efficacy (or, the sense of efficacy), and selfworth (Baumeister, 1991). These needs for meaning constitute four patterns of motivation that guide how people try to make sense of their lives. It seems that Baumeister agrees with Bandura's theory, for he emphasizes that people seek control over their environments, as well as over themselves, and that a lack of control can provoke a serious personal crisis that may have a negative impact on physical and mental health (Baumeister 1991; see also Baumeister and Vohs, 2002).

\section{Self-efficacy and health behaviour}

A general question here is the following one: Are there any health benefits of selfefficacy? On the whole, one of the strengths of the self-efficacy theory is its applicability to the practice of modifying and maintenance health behaviours. As indicated earlier in this article, a sense of personal efficacy (or perceived self-efficacy) is a key factor in the exercise of personal control over challenging demands, including control over the state of one's health. This personality variable is thought to be associated with specific positive health behaviours. In sum, there are many ways in which self-efficacy beliefs are important for human health, contributing to adaptive patterns of good physical and mental health.

Research guided by Bandura's theory on self-efficacy has greatly enhanced understanding of how and why people adapt healthy and unhealthy behaviours, and how to change behaviours that affect one's health. Beliefs about self-efficacy influence health in two key ways. First, such beliefs play influential role in adopting new healthy behaviours, in the initiation of health behaviours or the cessation of unhealthy behaviours or detrimental habits, and the maintenance 
of achieved behavioural changes in the face of challenge and difficulty. A people's belief that they can motivate themselves and regulate their own behaviours is of key importance whether they even consider changing their habits detrimental to health or pursuing rehabilitative activities (Bandura, 1997). Further, even people who acknowledge that their habits are harming their health achieve little success in curtailing their behaviour unless they judge themselves as having some efficacy to resist situational and emotional challenges (Strecher et al., 1985). In general, people who are high in self-efficacy tend to believe that they have more control over their own health and are able to ménage pain better. They also show better adherence to programs that attempt to increase their health, such as smoking cessation programs (see Brannon and Feist, 2000). The large body of research on this kind of influence has shown that enhancing self-efficacy beliefs is crucial to the successful change and maintenance of various patterns or forms of health-related behaviours in the face of obstacles and aversive experiences, including the following practices: stress management (stress response and coping), addictive behaviours, reducing sexual risk behaviour, AIDS-related health behaviour, smoking cessation, nutrition and weight control, adherence to medication requirements and suggested treatment or rehabilitation, regular physical exercise, healthy decision making and choices of healthy lifestyle, healthprotective behaviour, and disease detection behaviours such as breast self-examinations (for additional information on research results regarding these health - related practices see Luszczynska and Schwarzer, 2005).

Second, self efficacy beliefs also influence a number of biological processes that, in turn, influence health and disease. Bandura (1986) has argued that perceived self-efficacy is a crucial determinant of health-related stress reaction, and this general relationship is supported by extensive empirical evidence. It is also found that people with high self-efficacy beliefs respond with more adaptive ways or forms of coping when an illness is experienced; for instance, higher self-efficacy is associated with greater ability to withstand pain, as well as with frequent and successful use the coping strategies directed to problem (instead of using the mechanism of escaping) (Trouillet etal., 2009). Contemporary research with cancer patients suggests that selfefficacy is effective, in part, because it promotes positive appraisals of benefit finding. This study found that self-efficacy was associated directly with cognitive appraisals of personal growth and acceptance of life imperfections (Luszczynska, Mohamed, \& Schwarzer, 2005). This research work of Bandura and his associates on self-efficacy and health is particularly intriguing because they are part of a team of researchers who have shown with objective physiological measures that the level of self-efficacy predicts the response of the immune system to stress. This means that our believing that we are capable of rising to the challenge actually seems to confer a benefit by bolstering our own immune system ( Flett, 2007). Thus, in domain of stress, where stressors take diverse forms and can produce different patterns of psychological activation, self-efficacy beliefs affect the body's physiological responses to stress, including the immune system: the higher the growth in perceived self-efficacy, the better the immune status (Bandura, 1997, 2006). Prolonged impairment of the immune function increases vulnerability to infection. The lack of perceived control over environmental demands can increase susceptibility to infections and hasten the progression of disease. Related to this, selfefficacy beliefs influence the activation of catecholamines, a family of neurotransmitters important to the management of stress and perceived threat, along with the endogenous painkillers referred to as endorphins. These beliefs also affect vulnerability to emotional distress and depression: a low sense of self-efficacy is associated with depression, anxiety and helplessness (Bandura, 1997, 2001; O’Leary and Brown, 1995, see also Maddux, 2002).

Besides that, the concept of self-efficacy is also seen as the main and the most proximal predictor and antecedent of human behaviour, including health behaviour change and 
maintenance. There is a large body of research on self-efficacy as a predictor for the likelihood of an individual engaging in health behaviours showing that self-efficacy appears to be a consistently good, or even the best, predictor of a variety of human behaviours that influence health - the factor that determine which individuals will, and will not, perform such behaviours. This kind of research indicates an overall stronger relationship with health behaviours than some other personality variables such as "sense of coherence" ( the term coined by Antonovsky to describe the ability to perceive one's world as essentially meaningful and manageable; associated with coping with stress) or the construct of "locus of control" (personality trait first proposed by Rotter to encapsulate the idea of perceived control and then adapted by health psychologists to distinguish between those who attribute their state of health to themselves, powerful others, or chance). Self-efficacy appears to be a rather better predictor of health behaviour and is perhaps the best predictor available (Marks et al., 2011; Schwarzer, 1992).

\section{Implications and conclusions}

Bandura's influential self-efficacy theory has provided an important contribution to the study of various forms of human behaviour, including the patterns of health-related behaviour. The social-psychological concept of self-efficacy is concerned with people's beliefs in their own capabilities to mobilize the motivation, cognitive resources and courses of action needed to exercise control over given events and behaviours. It is the belief that humans are able to make changes in their behaviours, to perform or to learn the behaviours necessary to them to reach desired outcomes or goals. Diverse lines of research provide substantial empirical support for the crucial role of perceived self-efficacy in behaviour change, performance, and human adaptation.

In the article it is emphasized that self-beliefs of personal efficacy can have diverse effects on human behavioural functioning, including health-related functioning. Thus, such beliefs affect whether coping behaviour will be initiated, how much self-regulative effort will be expended, and how long this effort will be sustained in the face of obstacles and aversive experiences. Beliefs about self-efficacy influence health in two general ways: (1) they influence the adoption of healthy behaviours, the cessation of unhealthy behaviours, and the maintenance of behavioural changes in the face of challenge and difficulty; (2) they influence a number of biological processes that, in turn, influence health and disease. There is also a convincing body of research which documents that self-efficacy is a major determinant or predictor of engagement in health behaviours. In sum, the processes of self-regulation and self-efficacy beliefs are important for preventing distress and improving psychological wellbeing, contributing to adaptive patterns of good mental and physical health.

One of the aims of this article is to suggest that theory and research on self-efficacy may be relevant not only to various areas of applied psychology, including at first health psychology, but at the same time to some other scientific disciplines such as contemporary anthropology conceived as a broad, diverse, and basically interdisciplinary and comparative science, which uses various theoretical and methodological approaches in the study of humans in their biopsycho-sociocultural complexities. As such, breaking down strong disciplinary boundaries, anthropology inevitably includes different forms of the specialized study in order to provide knowledge on various aspects, dimensions and characteristics of human nature - physical (biological), evolutional, medical, sociocultural, psychological, etc. It is an important feature of identity of contemporary anthropology.

In particular, we argue that the concept of self-efficacy, especially in relation to human physical and mental health, can be of interest to the scholars within contemporary special field 
of medical anthropology. It is because in this diverse and expanding subdiscipline of anthropological science the necessity of health promotion and disease prevention have been recognized as the important ways of health education and coping with possible health risk factors, in order to avoid various more or less severe mental and physical diseases (e.g., Baciu, 2014).

Related to this proposal, it should be noted that medical anthropology is highly developed area of anthropology, especially in American anthropology, which is defined as the study of human health and disease, health care systems, and biocultural adaptation (Kuper and Kuper, 2004). The discipline is autonomous from any single subdiscipline, with strong potential for integration of physical and cultural anthropology (McElroy, 1996). Since its beginning, it was interested in holistic understanding of the health-disease process in human societies - i.e., the ways in which human mind and behaviour are related to health, and consequently to medicine and to society in general. As such, medical anthropology may initiate interdisciplinary dialogue between anthropology and medicine, as well as between anthropology and psychology (especially health psychology), on the various topics and issues such as interdisciplinary research in health problems, culture and patterns of adaptation and disease, health resources in changing cultures, stress, illness and healing, etc. By viewing humans from multidimensional and ecological perspectives, this subfield of sociocultural anthropology is focused on the examination of the ways in which culture and society are organized around or influenced by various issues of human health and health care practices, including the issues of education and promoting health (e.g., McElroy and Townsend, 1989; Seymour-Smith, 1990). Related to this, we suggest that in this examination the human self-efficacy beliefs related to various kinds of health issues may be relevant research topic. Recently, evolutionary and ecological perspectives have transformed medical anthropology from a traditional focus on cultural aspects of health and healing, and comparative study of medical systems, to a broader perspectives of human health in an environmental context. This transformation has joined different researchers and practitioners to generate a new synthesis in the anthropological study of health (McElroy, 2004).

More specifically, a dialogue between applied medical anthropology and social-cognitive theory of self-efficacy may challenge medical anthropologists to take this concept into consideration and health research. Thus, this concept may be relevant to medical anthropologists interested in cross-cultural studies that deal with the issues of human adaptation, because human adaptation subsumes a range of variable responses, including physical and behavioural modifications, coping strategies, cultural change, and so on (McElroy, 1996). On the other hand, this cross-cultural knowledge of cultural patterning of health behaviour may be important to self-efficacy theory, because what is needed here is the research that in addition to behavioural and cognitive constructs includes also cultural constructs. For, there is an increasing recognition of the impact of sociocultural mediated beliefs on health seeking and health promoting behaviours, as well as the need for culturally appropriate programs that may increase the effectiveness of health promotion effects. It could be said that besides social-psychological principles of self-efficacy, designing intervention strategies and programs directed at changing behaviours and ultimately health outcomes, must take into consideration the unique racial and cultural human characteristics of populations and sub-groups (e.g., Hendricks et al., 2005).

Additionally, ethnomedical theoretical perspective focuses on health beliefs and practices, cultural values, and social roles related to health in various societies. Within this theoretical framework of medical anthropology it is recognized that management of illness and disability also occur in a social and cognitive matrix, as well as that healing is often mediated by symbols and practices that induce conditioned neurophysiological and immune system response. Finally, theory and research on self-efficacy beliefs related to human health, from prevention to protection, may be of great importance to applied medical anthropologists which deliberately 
become advocates for the community and attempt to do research that is useful and ethical, using eclectic research methods ranging from qualitative to highly quantitative (e.g., McElroy, 1996). Together with previously mentioned in this paper, it also may contribute to interdisciplinary collaboration between health psychology and medical anthropology - subdisciplines interested in various health-issues in socio-cultural context.

In sum, it is known much about the relationship between self-efficacy beliefs and physical and mental health. Of course, there is much more to be known on self-efficacy and health behaviour change and maintenance, including the issues concerning health promotion and health prevention. Given the relationship between self-efficacy and health, this article has suggested one possible avenue of future interdisciplinary research, emphasizing some potentially important implications of the concept of psychological self-efficacy for contemporary medical anthropology.

\section{References}

Allbery IP, Munafo M. Key concepts in health psychology, Sage Publications, London; 2008.

Baciu A. An anthropological analysis on the casuistry of the emergency medical service. Glasnik ADS. 2014; 49: 111-120.

Bandura A. Self-efficacy: Toward a unifying theory of behavioral change. Psychological Review. 1977; 84: 191-215.

Bandura A. Social foundations of thought and action: A social cognitive theory, Prentice Hall, Englewood Cliffs NJ; 1986.

Bandura A. Exercise of personal agency through the self-efficacy mechanism. In R. Schwarzer (Ed.), Self-efficacy: Thought control of action, Hemisphere, Washington DC; 3-37.

Bandura A. Self-efficacy: The exercise of control, Freeman, New York; 1997.

Bandura A. Social cognitive theory: An agentic perspective. Annual Review of Psychology. 2001; 52: $1-26$.

Bandura A. Toward a psychology of human agency. Perspectives on Psychological Science. 2006; 1: 164-180.

Bandura A. An agentic perspective on positive psychology. In S.J. Lopez (Ed.), Positive psychology: Exploring the best in people, Greenwood Publishing Company, Westport CT; 2008; vol.1: 167-196.

Bandura A., Locke EA. Negative self-efficacy and goal effects revisited. Journal of Applied Psychology. 2003; 88 (1): 87-99.

Baumeister RF. Meaning of life, Guilford Press, New York NY; 1991.

Baumaister RF, Vohs KD. The pursuit of meaning fullness in life. In C.R.Snyder and S.J. Lopez (Eds), Handbook of positive psychology, Oxford University Press, New York NY; 2002, 608-619.

Brannon L, Feist J. Health psychology: An introduction to behavior and health $\left(4^{\text {th }}\right.$ ed.), Wadsword Belmont CA; 2000.

Compton WC. An introduction to positive psychology, Thomson Wadsworth Belmont CA; 2005.

Conner M, Norman P. predicting health behaviour: A social cognition approach. In M. Conner and P. Norman (Eds), Predicting health behaviour: Research and practice with social cognition models ( $2^{\text {nd }}$ ed.), Open University Press, Maidenhead; 2005, 1-27.

Flett GL. Personality theory \& research: An international perspective, John Wiley \& Sons Canada Ltd., Freemont Blvd; 2007.

Hendricks CS, Hemdricks DL, Webb SJ, Davis JB, Spencer-Morgan B. Fostering self-efficacy as an ethical mandate in health promotion practice and research. Online Journal of Health Ethics. 2005; 2(1): 1-13. http://dx.doi.org/10.18785/ojhe.0201.06.

Kaptein A, Weinman J (Eds). Health psychology, Blackwell, Oxford; 2004.

Kuper A, Kuper J (Eds). The social science encyclopedia, Routledge, New York.

Luszczynska A, Shwarzer R. Social cognitive theory. In M. Conner and P. Norman (Eds), Predicting health behaviour: Research and practice with social cognition models $\left(2^{\text {nd }}\right.$ ed.), Open Univerity Press, Maidenhead; 2005; 127-169. 
Luszczynska A, Mohamed NE, Schwarcer R. Self-efficacy and social support predict human benefit finding 12 months after cancer surgery: The mediating role of coping strategies. Psychology, Health, and Medicine. 2005; 10: 365-375.

Maddux JE. Self-efficacy: The power of believing you can. In C.R. Snyder and S.J. Lopez (Eds), Handbook of positive psychology, Oxford University Press, New York NY; 2002, 277-287.

Marks DF, Murray M, Evans B, Estacio E.V. Health psychology: Theory, research and practice, Sage Publications, London; 2011.

McElroy A. Should medical ecology be political? Medical Anthropology Quarterly. 1996; 10(4): 519-522.

McElroy A. Evolutionary and ecological perspectives. In C.R. Ember and M. Ember (Eds), Encyclopedia of medical anthropology: Health and illness in the world's cultures, Kluwer Academic, New York NY; 2004; 31-37.

McElroy A, Townsend PK. Medical anthropology in ecological perspective ( $2^{\text {nd }}$ ed.), Westview Press, Boulder Colo; 1989.

Norman P, Conner M. Predicting and changing health behaviour: Future directions. In M. Conner and P. Norman (Eds), Predicting health behaviour: Research and practice with social cognition models, Open University Press, New York NY; 2005; 324-371.

O'Leary A, Brown S. Self-efficacy and the psychological stress response. In J.E. Maddux (Ed.), Selfefficacy, adaption, and adjustment: Theory, research, and application, Plenum Press, New York NY; 1995; 227-248.

Rodham K. Health psychology, Palgrave Macmillan, London; 2010.

Schwarzer R. Self efficacy in the adaptation and maintenance of health behaviours: Theoretical approaches and a new model. In R. Schwarzer (Ed.), Self efficacy: Thought control of action, Hemisphere, Washington DC; 1992; 217-243.

Seymour-Smith C. Macmillan dictionary of anthropology, Macmillan Press, London; 1990; 187-188/

Strecher VJ, Becker MH, Kirscht JP, Eraker SA, Graham-Tomasi RP. Psychosocial aspects of changes in cigarette-smoking behavior. Patient Educ.Couns. 1985; 7: 249-262.

Strecher VJ, Devellis BM, Becker MH, Rosenstock, IM. The role of self-efficacy in achieving health behavior change. Health Education. 1986; 13 (1): 73-91.

Tronillet R, Gana K, Lourel M, Fort I. Predictive value of age for coping: The role of self-efficacy, social support satisfaction and perceived stress. Aging and mental health. 2009; 13: 357-366.

Zlatanović Lj. Positive psychology: Implications for mental and physical health. Godišnjak za psihologiju. 2012; 9(11): 17-24.

\title{
SAMOEFIKASNOST I ZDRAVO PONAŠANJE: NEKE IMPLIKACIJE ZA MEDICINSKU ANTROPOLOGIJU
}

\author{
Ljubiša Zlatanović
}

Sažetak. Proučavanje karakteristika ličnosti i ponašanja povezanih sa ljudskim zdravljem postala je ključna oblast istraživanja u savremenoj zdravstvenoj psihologiji. Varijabla ličnosti koja je privukla rastuće interesovanje zdravstvenih psihologa je pojam samoefikasnosti koji je razvio Albert Bandura u svojoj veoma uticajnoj socijalno-kognitivnoj teoriji ljudskog ponašanja ili teoriji socijalnog učenja. Definisana uopšteno kao verovanje pojedinca da će biti u stanju da uspešno sprovede svoje planove i namere ili da izvrši određena ponašanja neophodna da bi se postigli željeni ciljevi ili anticipirani ishodi, samoefikasnost je jedan od ključnih faktora u sprovođenju lične kontrole, uključujući kontrolu nad sopstvenim stanjem zdravlja. Polazeći od ovog teorijskog okvira, glavna svrha ovog članka je da najpre pruži sažet prikaz teorije samoefikasnosri, a zatim da razmotri njenu povezanost sa raznim oblicima ili obrascima ponašanja u vezi sa zdravljem, kao i da sugeriše neke moguće implikacije ove teorije za medicinsku antropologiju - posebno za njene primenjene oblasti koje su fokusirane na zdravstvenu edukaciju, promovisanje i zaštitu zdravlja.

Ključne reči: samoefikasnost, zdravo ponašanje, zdravstvena psihologija, medicinska antropologija. 